\title{
HUBUNGAN POLA ASUH ORANG TUA DENGAN TINGKAT HOMOSEKSUAL PADA KOMUNITAS GAYX DI MANADO
}

\author{
${ }^{1}$ Maria M. Pontoh \\ ${ }^{2}$ Hendri Opod \\ ${ }^{2}$ Cicilia Pali
}

\author{
${ }^{1}$ Kandidat Skripsi Fakultas Kedokteran Universitas Sam Ratulangi Manado \\ ${ }^{2}$ Bagian Psikologi FakultasKedokteran Univeristas Sam Ratulangi Manado \\ Email: pontohmichelle@yahoo.com
}

\begin{abstract}
Nowadays, we can easily find people around us who are attracted to their own gender (homosexual). Some experts believe that the main cause is multifactorial; one of them is parenting style. This study aimed to obtain the relationship between parenting style and homosexual level. This was an observational analytical retrospective study with a cross sectional design. Samples were 76 members of the gays of X community in Manado obtained by using total sampling method. The instruments used were parenting style questionnaire and homosexual level questionnaire. Data were analyzed by using Spearman correlation test. The Spearman correlation test showed a p value $=0.039(<\alpha=0.05)$ which indicated that there was a relationship between parenting styles and the level of homosexual with a correlation of 0.237 that belonged to the low category. It means that parenting styles affect the level of the homosexual. The better the parenting style, the less the homosexual behavior. Conclusion: There was a positive relationship between parenting style and the homosexuality level of gays of X community in Manado.
\end{abstract}

Keywords: parenting style, homosexual level

\begin{abstract}
Abstrak: Dewasa ini, sering dijumpai orang yang menyukai sesama jenis (homoseksual). Para ahli berpendapat bahwa penyebabnya multifaktorial; salah satu diantaranya ialah pola asuh orang tua. Penelitian ini bertujuan untuk mengetahui hubungan antara pola asuh orang tua dengan tingkat homoseksual seseorang. Jenis penelitian ini retrospektif observasional dengan rancangan potong lintang yang bersifat analitik. Sampel ialah anggota komunitas gay X dikota Manado yang berjumlah 76 orang, diperoleh dengan metode total sampling. Instrumen penelitian ialah kuesioner pola asuh dan kuesioner tingkat homoseksual. Data dianalisis menggunakan uji korelasi Spearman. Hasil uji korelasi Spearman mendapatkan nilai $\mathrm{p}=0,039$ $(<\alpha=0,05)$ dengan nilai korelasi 0,237 yang termasuk dalam kategori rendah. penelitian mendapatkan adanya hubungan antara pola asuh orang tua dengan tingkat homoseksual pada gay dalam komunitas X di kota Manado. Semakin baik pola asuh yang diterapkan, semakin berkurang perilaku penyimpangan seksual seseorang. Simpulan: Terdapat hubungan positif antara pola asuh orang tua dengan tingkat homoseksual pada gay dalam komunitas $\mathrm{X}$ di Manado.
\end{abstract}

Kata kunci: pola Asuh, tingkat homoseksual

Manusia merupakan makhluk hidup ciptaan Tuhan yang mempunyai naluri untuk mencari pasangan hidup. Dalam menentukan pasangan hidup, masingmasing orang mempunyai kecendeerungan yang disebut orientasi seksual. Orientasi seksual terbagi menjadi heteroseksual (ketertarikan terhadap lawan jenis), homoseksual (ketertarikan terhadap sesama jenis) dan biseksual (ketertarikan terhadap 
lawan jenis dan sesama jenis. Homoseksual merupakan salah satu kelainan seksual berupa disorientasi terhadap pasangan seksual-nya; pada pria disebut gay dan pada perempuan disebut lesbian. ${ }^{1}$

Ada banyak faktor yang diduga menjadi pengaruh penyimpangan seksual pada seseorang, baik itu dari luar maupun dalam diri seseorang termasuk pengalaman masa kanak - kanak, khususnya interaksi antara anak dan orang tua. ${ }^{2}$

Pola asuh orang tua merupakan hal yang berperan penting dalam menentukan sikap dan tingkat anak. Dalam sebuah wawancara dengan seorang gay, dapat diperoleh kesimpulan sementara bahwa pengalaman masa kanak - kanak yang tidak menyenangkan dengan perlakuan orang tua yang terlalu keras maupun orang tua yang tidak peduli terhadap anaknya telah menjadi pendorong yang kuat bagi munculnya penyimpangan seksual. Anakanak ini kemudian bergabung dalam komunitas gay dimana mereka merasa lebih diterima. ${ }^{3}$

Komunitas $\mathrm{X}$ merupakan komunitas gay yang terdiri dari 76 anggota. Anggota komunitas ini berasal dari berbagai latar belakang dan lapisan social ekonomi yang berbeda, namun karakteristik yang menonjol dari mereka dapat dilihat dari cara mengekspresikan diri mereka, penampilan fashionable, mengikuti trend, gaya hidup hedonistic, pleasure oriented, sering berkumpul di tempat umum yang ramai..

Komunitas gay merupakan bagian dari komponen masyarakat yang memengaruhi pola tingkat masyarakat, tetapi sampai saat ini kajian ilmiah terhadap komunitas ini masih sangat terbatas.

\section{METODE PENELITIAN}

Penelitian ini menggunakan metode retrospektif observasional dengan rancangan potong lintang yang bersifat analitik. Penelitian ini dilakukan pada bulan Januari 2015. Sampel penelitian yaitu di komunitas gay X di Manado, diperoleh secara total sampling. Data dianalisis menggunakan SPSS versi 21.

\section{HASIL PENELITIAN DAN BAHASAN}

Dari seluruh anggota komunitas yang berjumlah 76 responden, didapatkan 82 responden yang bersedia mengisi kuesioner dan diantaranya ada 76 responden yang mengisi kuesioner dengan lengkap. Hasil penelitian menunjukkan bahwa terdapat 19 responden (25\%) yang dibesarkan dengan pola asuh authoritative, 16 responden (21,1\%) dengan pola asuh authoritarian, 16 responden $(21,1 \%)$ dengan pola asuh indulgent dan 25 responden (32,9\%) dengan pola asuh indifferent.

Tabel 1. Distribusi Sampel Berdasarkan Tingkat Homoseksual

\begin{tabular}{ccc}
\hline $\begin{array}{c}\text { Tingkat } \\
\text { Homoseksual }\end{array}$ & Frekuensi & Persentase \\
\hline 0 & 0 & $0,0 \%$ \\
1 & 0 & $0,0 \%$ \\
2 & 0 & $0,0 \%$ \\
3 & 18 & $23,7 \%$ \\
4 & 19 & $25,0 \%$ \\
5 & 21 & $27,6 \%$ \\
6 & 18 & $23,7 \%$ \\
Total & 76 & $100,0 \%$ \\
\hline
\end{tabular}

Dari Tabel 1 didapatkan bahwa terdapat 18 responden (23,7\%) pada tingkat 3, 19 responden (25\%) pada tingkat 4, 21 (27,6\%) responden pada tingkat 5 dan 18 responden $(23,7 \%)$ pada tingkat 6 . Tidak ada responden yang memiliki tingkat homoseksual antara 0 sampai 2, karena kategori tersebut masih termasuk dalam kategori heteroseksual. Semua responden dalam komunitas gay $\mathrm{X}$ memiliki hasil biseksual dan homoseksual karena penelitian dilakukan dalam komunitas dengan anggota yang notabene memiliki penyimpangan seksual dengan skala 3-6. Masing-masing tingkat homoseksual mempunyai jumlah yang tidak jauh berbeda. Ini menandakan bahwa di dalam komunitas gay $\mathrm{X}$ tersebut di tingkat homoseksual anggotanya bervariasi dan tidak terpusat pada satu tingkat homoseksual saja. Dari hasil yang tidak jauh berbeda, didapatkan tingkat homoseksual terbanyak berada pada tingkat 5 dengan jumlah responden sebanyak 21 orang. 
Tabel 2. Distribusi Sampel Berdasarkan Tingkat Homoseksual dan Pola Asuh

\begin{tabular}{ccccc}
\hline \multirow{2}{*}{$\begin{array}{l}\text { Tingkat } \\
\text { Homosek } \\
\text { sual }\end{array}$} & \multicolumn{4}{c}{ PolaAsuh } \\
\cline { 2 - 5 } & $\begin{array}{l}\text { Authorita } \\
\text { tive }\end{array}$ & $\begin{array}{c}\text { Authorita } \\
\text { rian }\end{array}$ & $\begin{array}{c}\text { Indulg } \\
\text { ent }\end{array}$ & $\begin{array}{c}\text { Indiffer } \\
\text { ent }\end{array}$ \\
\hline 0 & 0 & 0 & 0 & 0 \\
1 & 0 & 0 & 0 & 0 \\
2 & 0 & 0 & 0 & 0 \\
3 & 9 & 3 & 2 & 4 \\
4 & 3 & 7 & 3 & 6 \\
5 & 2 & 5 & 7 & 7 \\
6 & 5 & 1 & 4 & 8 \\
Total & 19 & 16 & 16 & 25 \\
\hline
\end{tabular}

Berdasarkan penelitian yang dilakukan terhadap 76 responden, didapatkan hasil bahwa sebagian besar anggota komunitas dibesarkan dengan pola asuh indifferent, yakni berjumlah 25 orang. Orang tua dengan pola asuh indifferent memiliki control tingkah laku yang rendah dan cenderung membiarkan sang anak untuk bebas melakukan apa saja, sehingga anak tidak takut untuk mengambil keputusan penting untuk dirinya sendiri termasuk dalam hal menjalin hubungan dengan sesama jenis. $^{3-5}$

Pola asuh authoritative dipercaya merupakan pola asuh yang paling baik karena cara berpikir orang tua tidak lagi kolot, dimana hal ini dipengaruhi oleh pendidikan yang tinggi dan lingkungan tempat tinggal orang tua. Namun hasil penelitian yang menunjukan jumlah responden yang dibesarkan dengan pola asuh authoritative berada diperingkat ke dua, menunjukkan indikasi pola asuh bukan merupakan satu - satunya faktor yang menyebabkan seseorang menjadi homoseksual. Diluar pola asuh orang tua, faktor pergaulan, kebudayaan dan motivasi dari dalam diri juga bisa memengaruhi orientasi seksual seseorang. ${ }^{6,7}$

Jumlah responden yang dibesarkan dengan pola asuh orang tua authoritarian dan indulgent memiliki jumlah yang sama yaitu 16 responden. Orang tua yang membesarkan anak dengan pola asuh authoritarian cenderung mendidik anak dengan keras, disipin tinggi, dan tidak menjalin hubungan akrab dengan sang anak. Anak yang dibesarkan dengan pola asuh ini cenderung dilakukan untuk dilakukan untuk membalas dendam, guna mencari perhatian maupun kebebasan yang selama ini tidak didapat dari orang tua.,

Tabel 3. Analisis Hubungan Antara Pola Asuh dengan Tingkat Homoseksual

\begin{tabular}{||l|l|r|r|}
\hline \multicolumn{2}{|c|}{} & $\begin{array}{r}\text { Pola } \\
\text { Asuh }\end{array}$ & \multicolumn{1}{c|}{$\begin{array}{c}\text { Perilaku } \\
\text { Homoseks } \\
\text { ual }\end{array}$} \\
\hline PolaAsuh & $\begin{array}{l}\text { Correlation } \\
\text { Coefficient }\end{array}$ & 1,000 &, $237^{*}$ \\
\cline { 2 - 4 } & Sig. (2-tailed) &. &, 039 \\
\cline { 2 - 4 } & N & 76 & 76 \\
\hline $\begin{array}{l}\text { Perilaku } \\
\text { Homoseksual }\end{array}$ & $\begin{array}{l}\text { Correlation } \\
\text { Coefficient }\end{array}$ &, $237^{*}$ & 1,000 \\
\cline { 2 - 4 } & Sig. (2-tailed) &, 039 & \\
\cline { 2 - 4 } & N & 76 & \\
& & & \\
& & & \\
& & & \\
\hline
\end{tabular}

Dari hasil penelitian tentang hubungan antara pola asuh orang tua terhadap tingkat homoseksual pada komunitas gay $\mathrm{X}$ seperti pada tabel 4, didapati bahwa nilai koefisien korelasi antara pola asuh orang tua terhadap tingkat homoseksual pada komunitas gay X di Manado menggunakan tingkat signifikan $\alpha=95 \%$ atau 0,05, dengan nilai $r=, 0237$ atau sebesar $23,7 \%$. Jadi tingkat homoseksual pada komunitas gay di Manado dipengaruhi oleh pola asuh orang tua sebesar 23,7\%. Sebesar 76,3\% dipengaruhi oleh faktor lain yang tidak dibahas pada penelitian ini.

Tingkat hubungan berdasarkan nilai koefisien, dapat disimpulkan bahwa tingkat hubungan antara pola asuh orang tua terhadap tingkat homoseksual pada komunitas gay di Manado $(\mathrm{r}=.0237)$ tergolong rendah.

\section{SIMPULAN}

Berdasarkan hasil penelitian dapat disimpulkan bahwa terdapat hubungan positif antara pola asuh orang tua dengan tingkat homoseksual.

\section{SARAN}

1. Untuk penelitian kedepan disarankan 
dapat dilakukan penelitian pada ruang lingkup yang lebih luas misalnya dalam satu kota.

2. Disarankan untuk melakukan lebih lanjut yakni mengenai faktor apa saja, selain pola asuh, yang memengaruhi tingkat homoseksual.

3. Sebelum penelitian sebaiknya diberikan edukasi yang baik kepada responden agar tidak ada lembar jawaban yang hasilnya tidak lengkap.

\section{DAFTAR PUSTAKA}

1. Oetomo D. Memberi Suara Pada yang Bisu. Yogyakarta: Pustaka Marwa, 2003; 42.

2. Semiun Y. Kesehatan Mental 2. Yogyakarta: Kanisius, 2006; p. 46.

3. Hurlock EB. Child Growth and
Development. USA: Literary Licensing, 2013; p. 54.

4. Fernando J. Pengumpulan Alat Bukti dan Barang Bukti dalam Penyidikan terhadap Anak Korban Kekerasan Psikis yang Dilakukan oleh Orang tua Kandung [Skripsi]. Jogyakarta: Universitas Atmajaya; 2014.

5. Nwamaka G. Influence of Parenting Styles on Adolescent Delinquency in Delta Central Senatorial District. Delta State University, 2010.

6. Vines G. Raging Hormones. London: Virago Press, 1993; p. 111.

7. Safitri Y, Hidayati E.. Hubungan antara Pola Asuh Orang tua dengan Tingkat Depresi Remaja di SMK 10 November Semarang. Jurnal Keperawatan Jiwa. 2013;1(1):11-7. 